\title{
THE EFFECT OF LEARNING STYLES FOR ENGLISH SPEAKING SKILL
}

\author{
Abd. Ghofur \\ STKIP PGRI Lamongan \\ Lamongan, East Java, Indonesia \\ Email: ghofurkita@yahoo.com
}

\begin{abstract}
Everyone has a dominant learning style that allows them to easily absorb the information it receives. This paper is the result of a study corresponding author modalities influence students to absorb information on the differences in the English speaking skill. This research was conducted in class X SMA N 1 Lamongan. The study design using the ex post facto with a population of 383 and the number of samples 70. The data collection technique using questionnaires and tests the ability to speak English. Analysis using descriptive analysis and ANOVA one lane using parametric statistical methods. This is done because it is based on a statistical test, the normal distribution of research data and homogeneous. The results showed that students who have a visual learning style as many as 32 people, with a mean of 69.56 and a standard deviation of 12.281. Then students who have auditory learning styles as many as 20 people with a mean of 66.10 with a standard deviation of 10.935. While students who have a kinesthetic learning style as many as 18 people with a mean of 66.28 and a standard deviation of 12.942. The results of data analysis known that the significance value (sig.) Of 0.511. This showed that no significant difference in the English speaking skill among students who have learning styles of visual, auditory and kinesthetic.
\end{abstract}

Keywords: Learning Styles, English Speaking Skills

\section{INTRODUCTION}

For most high school students, speaking in English it is still difficult. This perception continues to build that into the belief by most students that English speaking skill was difficult to achieve. So as to change the mindset of students related to the perception of spoken English from difficult to easy to be very helpful. It is based on the opinion of Nazara (2011) that the perception of the students about her abilities related to the level of speaking ability will motivate them to develop English speaking skill. What do teachers in guiding the learning activities are also a major influence on perceptions of learners understand the activities speak English they learned.

Perception difficult will speak English experienced by the students triggered them shame and fear when they are asked to communicate using English. It is based on research results Bashir, et al (2011) found difficulty speaking English starting from shyness to express it. Shyness makes it difficult to develop students' speaking abilities which lead students do not get a chance to speak English, both inside and outside the classroom.

In addition to these problems, according to Ahmed (2012), there are several factors that influence the success of learning a foreign language, one of which is the student's learning style. Classification of perceived student learning styles can help students easily receive information in accordance with the modalities owned. The study results Nunan (1991) explains that learning style is the key to developing a performance at work, at school, and in interpersonal situations. When he realized how a person absorb and process information, learn and communicate into something easy and fun.

Clarify the above opinion, White (2004) wrote in an article that every child has three learning modalities, namely visual, auditory and kinesthetic. Therefore, most learners to filter, process, and communicate in learning to use these modalities. Modalities Visual access the visual images created or retained. For example, color, spatial relationships, pictures, and more. While auditory modalities to access all kinds of sounds and words that are created or retained, for example music, tone, rhythm, rhyme, 
dialogue and so on. Then kinesthetic modalities of accessing things done or given to the movements and emotions, such as coordination of movement, emotional response to the rhythm and physical comfort.

$\mathrm{Xu}$ (2011) in an article explaining that the possible visual students become good readers while students auditory can become articulate and communicate. Language teachers should put the student's learning style differences in the learning process and teach it balanced. Different teaching approaches can be integrated in the form of different tasks or activities to please all the students so that the achievements of the teaching will be better.

Gilakjani (2012) conducted a study to determine the students' learning styles and their impact in learning English in Iran. Results in classes where the study shows that visual learning style of the most dominating, followed auditory and kinesthetic. He also revealed that students learn best by seeing the value and importance of the information presented in class. If students are not interested in the material submitted, they will not learn. Classification of students' learning styles will enable students to define their own personal strengths and weaknesses and learn from it. Teachers can use the students' learning styles in the classroom by identifying ways of learning of each student, then adjust teaching styles to learning styles for the provision of hard or easy task, and also the adjustment of learning strategies with a variety of learning styles of the students.

In addition, the results Ampa, et al (2013) recommend the student's learning style classification consisting of visual, auditory and kinesthetic learning in designing related to the ability to speak English. Results of analysis showed that the frequency of the use of visual learning style 54\%, then $68 \%$ Auditory and Kinesthetic 39\%. Based on various studies, the authors try to assess whether there is any difference in the English speaking skill among the group of students who have a visual, auditory and kinesthetic learning style.

\section{METHOD}

This study design was causal comparative research (ex post facto), it aims to reveal possible causal relationships between variables without manipulating variable. That is, the variables to be tested casual relationship has occurred in reasonable condition. Research in this plan implemented by way of observing the variable first and then the result of observation of variables that allegedly caused it. The population in this study were 383 imposed as a sample of 70 students. The technique of collecting data using questionnaires and tests. A questionnaire was used to identify students' learning styles. Learning styles questionnaire used in this study using a questionnaire developed by DePorter and Hernacki (2000). Instruments learning styles questionnaire was used to assess whether the student has a tendency learning style visual, auditory or kinesthetic. The instrument for each learning style is composed of 12 of the questions. Each question was given a choice of three answers to choose one, namely: often, sometimes, rarely. In all three instruments are each student will fill by giving a check mark $(\sqrt{ })$ in the column answers, namely $\mathrm{O}$ for Often, $\mathrm{S}$ for Sometime and $\mathrm{R}$ for Rarely. Many questions are checked for each questionnaire is given a value, which is the formula as follows:

\section{Learning Style Values $=\sum O \times 2+\sum S \times 1+\sum R \times 0$}

Scores will be obtained from each instrument that represents the learning styles were then compared. Score the highest instrument shows the tendency of learning styles that are owned by the student. With this instrument the students can be grouped into three categories, namely students who have learning styles of visual, auditory and kinesthetic. For the needs of statistical analysis, all three learning styles are categorized $(1=$ visual, $2=$ auditory, $3=$ kinesthetic $)$.

The test is used to determine the level of students' ability to speak English. There are 10 aspects of assessment, including aspects of content (content), grammar (grammar), the kind of words (vocabulary), clarity (fluency), pronunciation (pronunciation), intonation, word choice (diction), organizing, interactive communications, discourse management, with a score of each aspect of a maximum of 5 and a minimum assessment 1. the tenth aspect is used to assess the English speaking through monologues and

The $8^{\text {Th }}$ International Conference on Educational Technology of Adi Buana, 29 October 2016 
interpersonal, the accumulated value of the lowest end of 20 and the highest score of 100 . The analysis of data using descriptive analysis and one way ANOVA.

\section{FINDINGS AND DISCUSSION}

Based on the analysis of learning styles questionnaire on research class as a whole, it is known that students who have visual styles as many as 32 people, and students who have auditory learning styles as many as 20 people, while students who have a kinesthetic learning style as many as 18 people.

Before analyzing the study data to determine whether there is difference in the ability to speak English among groups of students who have learning styles of visual, auditory and kinesthetic, author of the first to test the prerequisite. Prerequisite test in question is a test of normality and homogeneity of data, it is intended to determine the statistical methods used to analyze the research data.

Normality test data is performed on the null hypothesis (Ho) which states that the sample comes from a population that is normally distributed. Criteria for acceptance and rejection of the hypothesis is based on (1) if the value is significant (sig.) Or a probability of less than 0.05 alpha means of data distribution is not normal, and (2) if the value is significant (sig.) Or a probability of more than 0.05 alpha means the normal data distribution.

Based on calculation of data normality test the ability to speak English to the students' learning styles (visual, auditory, and kinesthetic) with SPSS version 16.0 presented as Table 1 below.

Table 1. Test Normality value the students' English speaking skill based on learning styles

\begin{tabular}{|c|c|c|c|c|c|c|c|}
\hline \multicolumn{8}{|c|}{ Tests of Normality } \\
\hline & \multirow[b]{2}{*}{ Gaya_Belajar } & \multicolumn{3}{|c|}{ Kolmogorov-Smirnov ${ }^{a}$} & \multicolumn{3}{|c|}{ Shapiro-Wilk } \\
\hline & & Statistic & Df & Sig. & Statistic & Df & Sig. \\
\hline \multirow[t]{3}{*}{ Posttest } & Visual & .114 & 32 & $200^{*}$ & .951 & 32 & .151 \\
\hline & Auditorial & .162 & 20 & .182 & .959 & 20 & .515 \\
\hline & Kinestetik & .164 & 18 & $.200^{\star}$ & .943 & 18 & .320 \\
\hline
\end{tabular}

a. Lilliefors Significance Correction

*. This is a lower bound of the true significance.

Based on the test Lilliefors Significance Correction of Kolmogorof-Smirnov as shown in Table 1 above that the value of significance (sig.) In the group of students who have a visual learning style is $0.200 \geq 0.05$, then the value of significance (sig.) Group of students who have learning style auditory is 0.182 , which means also greater than 0.05 , whereas in the group of students who have a kinesthetic learning style significance value (sig.) data is 0.200 which is also greater than 0.05 . So that it can be concluded that the data is the result of the English speaking skill is based on the student's learning style experimental class and control class normal distribution. To strengthen the normality of the data, plot graphs are presented as shown in Figure 1, Figure 2 and Figure 3 below. 


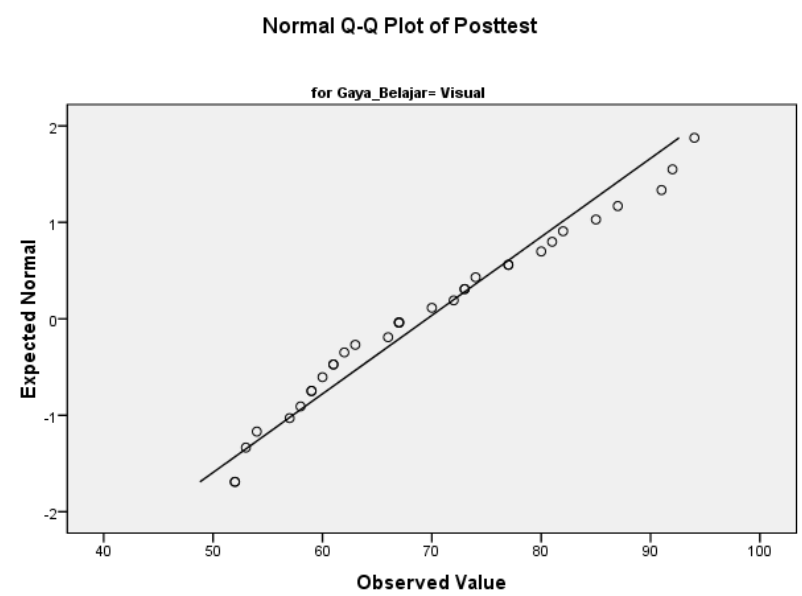

Figure 1 Graph Normal Q-Q plot of posttest-Visual Learning Styles

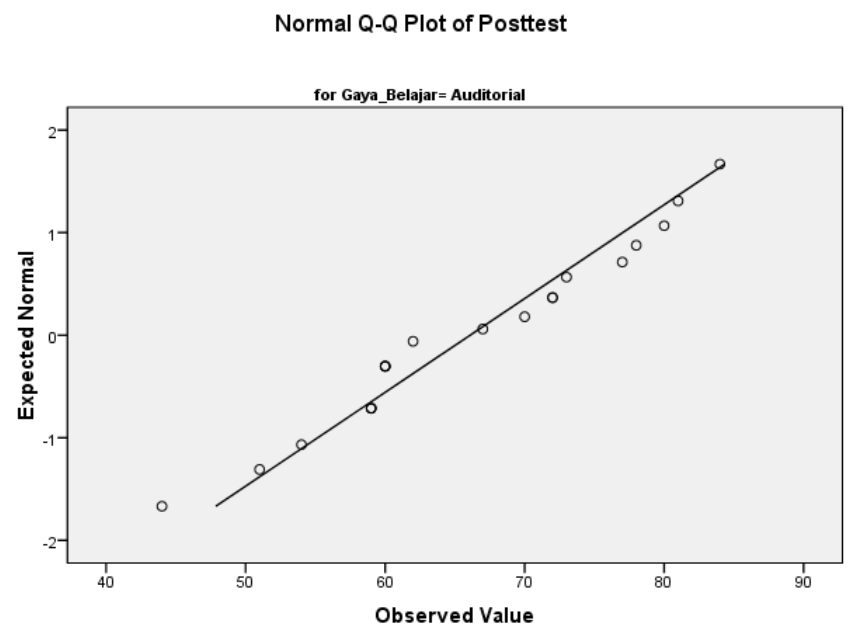

Figure 2 Graph Normal Q-Q plot of posttest-Auditory Learning Styles

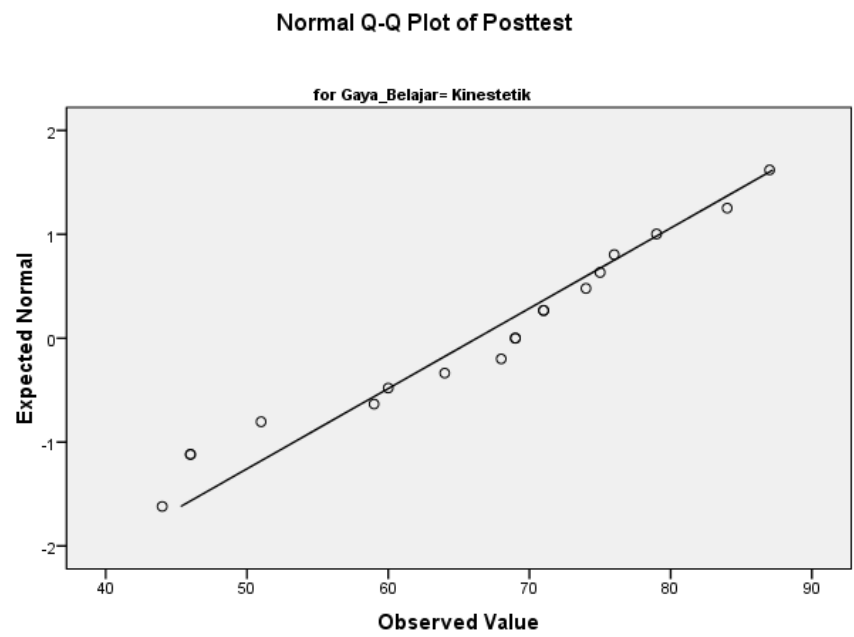

Figure 3 Graph Normal Q-Q plot of posttest-Kinesthetic Learning Styles 
In the graph shown in Figure 1, Figure 2 and Figure 3 above is known that the normal QQ plot, both on the learning styles of visual, auditory and kinesthetic look no straight line from left to right top and data scattered around the line, so it can be said that the data the normal distribution.

The next prerequisite test is the test of homogeneity. Homogeneity testing is used to show that two or more groups of data samples come from population which have the same variance. Testing homogeneity of variance samples in this study conducted on learning outcomes of the ability to speak English. Testing homogeneity of the sample variance using Levene's Test with a significance level of 0.05 . The criteria for determining the homogeneity of variance test samples can be done by comparing the results count towards learning outcomes significance level of 0.05 . If the significance value less than 0.05 then said to the sample data comes from populations having variances are not equal or heterogeneous. On the contrary, if the significance value> 0.05 then said to the sample data comes from populations having the same variance or homogeneous. Based on the results of the statistical count shown in Table 3 below are unknown significance value of 0.321 , which means greater than 0.05 . It can be concluded that Ho is accepted, it means that the sample variances homogeneous.

Table 2 Test Homogeneity value the students' English speaking skill

\section{Levene's Test of Equality of Error Variances ${ }^{a}$}

Dependent Variable:Posttest

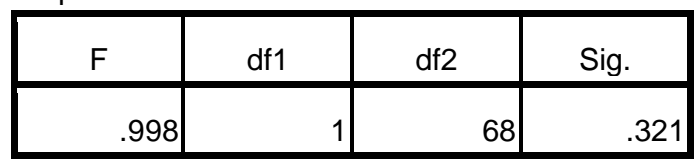

Tests the null hypothesis that the error variance

of the dependent variable is equal across groups.

a. Design: Intercept + Metode

The test results showed that the prerequisite normal data distribution and homogeneous. So that it can be concluded that the data were analyzed using one way ANOVA with parametric statistical methods.

Based on the statistical studies, the authors analyze the data value the ability to speak English students in terms of learning style. Based on the analysis of descriptive note that the group of students who have a visual learning style are 32 students on average the English speaking skill was 69.56 with a standard deviation of 12 281. Then average the English speaking skill auditory student groups totaling 20 students was 66.56 with a standard deviation of 10935 . While groups of students who have a kinesthetic learning style average value is the English speaking skill was 66.28 with a standard deviation of 12942 . The detailed results of the descriptive analysis of data can be seen in Table 3, below.

Table 3. Descriptive analysis of Students' English speaking skill in terms of learning styles

Descriptive Statistics

Dependent Variable:Posttest

\begin{tabular}{|l|r|r|r|}
\hline Gaya_Belajar & Mean & Std. Deviation & \multicolumn{1}{|c|}{$\mathrm{N}$} \\
\hline Visual & 69.56 & 12.281 & 32 \\
Auditorial & 66.10 & 10.935 & 20 \\
Kinestetik & 66.28 & 12.942 & 18 \\
Total & 67.73 & 12.035 & 70 \\
\hline
\end{tabular}

The $8^{\text {Th }}$ International Conference on Educational Technology of Adi Buana, 29 October 2016 
Based on the purpose of the study, performed data analysis to determine whether there is any difference in the students' English speaking skill in terms of learning style. Therefore the statistical hypothesis in this study as follows, Ho: there is no difference in the English speaking skill among the group of students who have learning styles of visual, auditory and kinesthetic, and Ha: there are differences in the English speaking skill among the group of students who have a visual learning style, auditory and kinesthetic. Decision-making is based on a probability value, that is, if the value of significance (sig.) $>0.05$ then Ho is accepted and if the significance value (sig.) $<0.05$ then Ho is rejected. The detailed analysis of the data to determine whether there is a difference between the ability to speak English all three learning styles that can be known in Table 4 below.

Table 4. Data analysis the Students' English speaking skill in terms of learning styles

Tests of Between-Subjects Effects

Dependent Variable:Posttest
\begin{tabular}{|l|r|r|r|r|r|}
\hline Source & $\begin{array}{c}\text { Type III Sum of } \\
\text { Squares }\end{array}$ & Df & Mean Square & F & Sig. \\
\hline Corrected Model & $198.557^{2}$ & 2 & 99.278 & .679 & .511 \\
Intercept & 298086.402 & 1 & 298086.402 & $2.039 \mathrm{E} 3$ & .000 \\
Gaya_Belajar & 198.557 & 2 & 99.278 & .679 & .511 \\
Error & 9795.286 & 67 & 146.198 & & \\
Total & 331095.000 & 70 & & & \\
Corrected Total & 9993.843 & 69 & & & \\
\hline
\end{tabular}

a. R Squared $=.020$ (Adjusted R Squared $=-.009$ )

Based on the analysis of data as shown in Table 4 above, it is known that F count 0679 with a significance value is 0511 . Hence the significance value (sig.) $>0.05$, then Ho is accepted. This means that the average value of the English speaking skill among students who have learning style visual, auditory, and kinesthetic are not significantly different or no significant difference in the English speaking skill among students who have learning styles of visual, auditory and kinesthetic.

The result showed that there was no significant difference in the English speaking skill among students who have learning styles of visual, auditory and kinesthetic. This is due to the three groups of students who have different learning styles that have a value range average (mean) is not so much different. The group of students who have a visual learning style, scored an average of 69.56 with a standard deviation of 12.281. Then the group of students who have auditory learning style earned an average value of 66.10 with a standard deviation of 10935 . While groups of students who have a kinesthetic learning style earned an average value of 66.28 with a standard deviation of 12942 . Condition of the ability to speak English all three learning styles can be seen in Boxplot as presented in Figure 4 below. 


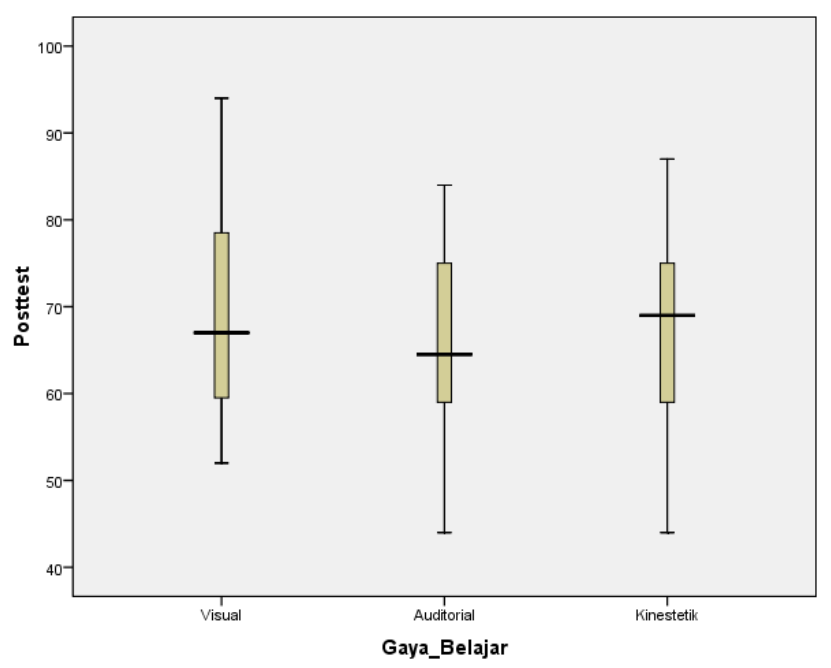

Figure 4 The students' English speaking skill Boxplot data between visual, auditory and kinesthetic learning styles

The absence of differences in the English speaking skill among the three groups of students who have learning styles that according to our analysis there are several reasons. First, the use of learning media to stimulate students understand the material in accordance with the perceived lack of optimal learning style. So most students are less able to absorb information from media that is used as part of a speaking activity.

Second, although the number of times the teacher reminded that speaking English was easy, but most students still can not completely eliminate their mindset related to speak English is difficult. This makes them learn in a state of distress. This condition is causing suboptimal students use their learning style so as to encourage the ability to speak English they grow and develop. It refers to the opinion of Nazara (2011) that the perception of the students about her abilities related to the level of speaking ability will motivate them to develop English speaking skill.

Third, differences in students' basic ability to dominate their English speaking skill. Learning styles only help students absorb the information on what is learned. But when they were asked to practice speaking English, students feel less confident on capabilities. This is made clear by the conclusion of the study Woodrow (2006) that many students are anxious related to lack of ability to speak at their disposal. As a result, many learners are scared when the material is related to the speaking skills.

\section{CONCLUSION}

Based on the findings and discussion in mind that there is no significant difference between the groups of students who have learning style visual, auditory and kinesthetic. There are some things that cause the absence of these differences, including: (1) the use of instructional media and other means to help students absorb the information and the material being taught is less optimal. (2) The average student still can not fully eliminate the perception that speaking English is easy, students are more worried about speaking it harder than on optimizing the learning style they have. (3) In general, learning styles can help students absorb the information being taught, but less able to apply in the activities of speaking in English.

\section{REFERENCES}

Ahmed, Omnia Nabih. 2012. The Effect of Different Learning Styles on Developing Writing Skills of EFl Saudi Learners. British Journal of Arts and Social Sciences. Volume 5 (2): Halaman 220-233.

Ampa, A. T., Rasyid, M. A., Rahman, A., Haryanto, Basri D, M. 2013. The Students' Needs in Developing Learning Materials for Speaking Skills in Indonesia. Journal of Education and Practice. Volume 4 (17): Halaman 171-178. 
Bashir, Marriam. Azeem, Muhammad. Dogar, Ashiq Hussain. 2011. Factor Effecting Students' English Speaking Skills. British Journal of Arts and Social Sciences. Volume 2 (1): Halaman 34-50.

De Porter, Bobbi, Reardon Mark, Singer Sarah dan Nourie. 2000. Quantum Teaching. Editor, Hernacki, Mike. Diterjemahkan oleh Ary Nilandari. Bandung: Kaifa PT Mizan Pustaka.

Gilakjani, Abbas Pourhossein. 2012. Visual, Auditory, Kinaesthetic Learning Styles and Their Impacts on English Language Teaching. Journal of Studies in Education. Volume 2 (1): Halaman 104113.

Nazara, Situjuh. 2011. Students' Perception on EFL Speaking Skill Development. Journal of English Teaching. Volume 1 (1): Halaman 28-43.

Nunan, David. 1991. Language Teaching Methodology: A Teksbook for teachers. Hertfordshire: Prentice Hall Int'l.

White, April. 2004. Impact of Student Motivation on Teaching and Learning. The Agriculture Educational Magazine. Volume 76 (4): Halaman 14-16.

Woodrow, Lindy. 2006. Anxiety and Speaking English as a Second Language. RERC Journal. Volume 37 (3): Halaman 308-328.

Xu, Wen. 2011. Learning Styles and Their Implications in Learning and Teaching. Theory and Practice in Language Studies. Volume 1 (4): Halaman 413-416

\section{BIODATA}

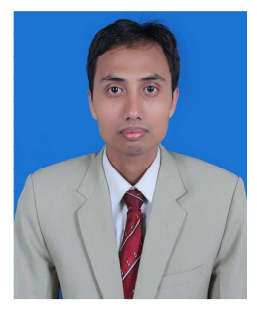

Abd. Ghofur, Born in Lamongan on January 26, 1987. Profession as a lecturer in STKIP PGRI Lamongan. In addition, he is also active in several activities in a scientific forum. 